\title{
Institutional arrangements in the commercialization of electric energy from sugarcane biomass in the Brazilian midwest
}

\author{
Arranjos institucionais na comercialização de energia elétrica de biomassa de \\ cana-de-açúcar na região centro-oeste do Brasil
}

\author{
Marli da Silva Garcia ${ }^{1}$ (D), Olivier François Vilpoux ${ }^{2}$ (D), Marney Pascoli Cereda ${ }^{3}$ (1) \\ ${ }^{1}$ Universidade Católica Dom Bosco, Campo Grande (MS), Brasil. E-mail: marliggarcia@gmail.com \\ ${ }^{2}$ Programa de Pós-graduação em Administração, Escola de Administração e Negócios (ESAN), Universidade Federal do Mato \\ Grosso do Sul (UFMS), Campo Grande (MS), Brasil. E-mail: o.vilpoux@gmail.com \\ ${ }^{3}$ Faculdade de Agronomia (FCA), Universidade Estadual do Estado de São Paulo (UNESP), Botucatu (SP), Brasil. E-mail: \\ mpcereda@gmail.com
}

\begin{abstract}
How to cite: Garcia, M. S., Vilpoux, O. F., \& Cereda, M. P. (2021). Institutional arrangements in the commercialization of electric energy from sugarcane biomass in the Brazilian midwest. Revista de Economia e Sociologia Rural, 59(3), e223028. https://doi.org/10.1590/1806-9479.2021.223028
\end{abstract}

\begin{abstract}
Reducing the use of fossil fuels and mitigating environmental impacts justifies the generation of electricity from renewable sources. In Brazil, sugarcane is the biomass that most generates electricity, and Mato Grosso do Sul state accounts for $10 \%$ of this electricity. Production can be traded in the spot market, long-term contracts regulated by the Federal Government, or free contracts between companies. Despite these options, only half of the sugarcane industries in Mato Grosso do Sul commercialize electricity. Based on Transaction cost economics, the objective of this work is to identify the most suitable governance structures used in the commercialization of electricity produced by the sugarcane plants in the state of Mato Grosso do Sul and to evaluate the institutional environment impact on these structures. A questionnaire was applied to all sugarcane companies in the state, and interviews were conducted with specialists and regulatory agencies. The results indicate that the widespread use of plural forms of governance for the commercialization of energy reduces the risks linked to a weak institutional environment and judicialization of the spot market. The preference for free contracts and a large number of short-term transactions indicate a lack of trust in the existing institutions, with the need to strengthen independent regulatory agencies.
\end{abstract}

Keywords: renewable energy, transaction cost economics, institutions, plural forms.

Resumo: Reduzir o uso de combustíveis fósseis e os impactos ambientais justifica a geração de eletricidade a partir de fontes renováveis. No Brasil, a cana-de-açúcar é a biomassa que gera mais energia elétrica e o estado do Mato Grosso do Sul é responsável pela geração de $10 \%$ dessa eletricidade. A produção pode ser negociada no mercado spot em contratos de longo prazo regulados pelo Governo Federal e em contratos livres, entre empresas. Apesar dessas opções, apenas metade das indústrias canavieiras do Mato Grosso do Sul comercializa eletricidade. Com base na Economia dos Custos de Transação, o objetivo desta pesquisa é identificar, dentre as estruturas de governança utilizadas, as mais adequadas para a comercialização da eletricidade produzida pelas usinas de cana-de-açúcar no estado de Mato Grosso do Sul, além de avaliar o impacto do ambiente institucional nessas estruturas. Um questionário foi aplicado a todas as empresas canavieiras do estado e foram realizadas entrevistas com especialistas e agências reguladoras. Os resultados indicam que o uso generalizado de formas plurais de governança reduz os riscos associados a um ambiente institucional fraco e à judicialização do mercado spot. A preferência por contratos livres e transações de curto prazo indica a falta de confiança nas instituições, com a necessidade de fortalecer agências reguladoras independentes.

Palavras-chave: energia renovável, economia dos custos de transação, instituições, formas plurais. 


\section{Introduction}

Global energy security is one of the priorities of developed countries and has been gaining a prominent role in the international debate. The International Energy Agency (2013) predicts a growth of $56 \%$ in the world energy consumption by 2040 . Still, according to the same source, most of this increase will come from countries such as China, India, Brazil, and South Africa, which have energy needs stimulated by economic growth.

Despite the growth projections in the world consumption, the Brazilian Ministry of Mines and Energy (Brasil, 2016) calculated a decrease of 1.3\% in the Brazilian electric energy supply between 2014 and 2015, mainly because of the recession, in addition to the drought in the Southeast region of the country.

The energy breakdown in drought regions may be explained by the national energy matrix, which is composed of 62\% hydropower (Agência Nacional de Energia Elétrica, 2015a). In 2015, the domestic electricity supply was 615.9 TWh. In that year, the sugar and alcohol sector as a whole generated 34.2 TWh, 13.7 TWh for own consumption, and 20.5 TWh for commercialization. The energy generation from sugarcane bagasse represented $70 \%$ of the total biomass power generation in Brazil. The remaining 30\% came mainly from black liquor, a waste generated by the pulp and paper industry (Brasil, 2016).

The electric energy production from sugarcane biomass may mitigate the socioeconomic impact of the energy shortage due to the availability of fuel, since each metric ton of sugarcane processed for the manufacture of sugar and ethanol produces, on average, $250 \mathrm{~kg}$ of bagasse and $200 \mathrm{~kg}$ of straw ${ }^{1}$ (Scaramucci et al., 2006). The bagasse has high fiber content and has been used since the industrial revolution for the production of steam and electric energy in the manufacture of sugar and ethanol distillation, guaranteeing the energy self-sufficiency of sugaralcohol plants during the harvest period. However, the straw is a residue that exists only when mechanized harvest occurs, a system implemented in Brazil less than a decade ago ${ }^{2}$.

The Sugarcane Industry Union (União da Industria de Cana de Açúcar, 2018) notes that for the 2016/2017 harvest, the processed sugarcane amounted to 651.8 million metric tons in Brazil. By using the index from Deshmukh et al. (2013), which establishes that one metric ton of sugarcane can produce $120 \mathrm{kWh}$ of energy, we estimate the total potential of energy production from sugarcane biomass in Brazil in 78.1 TWh, meaning more than twice the actual production.

In 2017, São Paulo was by far the largest producer, with $55.6 \%$ of the planted area (5,558.4 thousand hectares), followed by Goiás, with $9.0 \%$ ( 922.8 thousand hectares), Minas Gerais, with $8.9 \%$ (906.5 thousand hectares), Mato Grosso do Sul, with $6.5 \%$ (661.9 thousand hectares), and Paraná, with 6.3\% (643.6 thousand hectares) (União da Industria de Cana de Açúcar, 2018).

The state of Mato Grosso do Sul has an installed capacity to generate 8.7 million kW of power. Hydropower represents $77 \%$, thermoelectric units $20 \%$, and all other sources $3 \%$ of the state's installed power capacity (Agência Nacional de Energia Elétrica, 2014). Among the thermoelectric power plants in this state, those belonging to the sugar and alcohol industry account for $42 \%$ of the total, followed by the natural gas plants, with $35 \%$, and the diesel plants, with 23\% (Agência Nacional de Energia Elétrica, 2014). However, gas and diesel oil-fired power plants are only used to generate energy in the absence of other energy sources due to the high cost of production (Brasil, 2013).

In the state of Mato Grosso do Sul in 2016, there were twenty-four sugar-alcohol units processing sugarcane, of which two were deactivated. Among the twenty-two actives units, twelve were commercializing electricity, and one was investing to enter this market. One question that remains is why the other production units did not enter this market as well?

The question raises the necessity to analyze the governance structures of this sector to understand if they are well-shaped for an expansion of production. Thus, the objective of the present work is to identify the most suitable governance structures used in the

\footnotetext{
${ }^{1}$ It is necessary to point out that this straw should not be fully collected. For agronomic purposes, it is estimated that the withdrawal should be in the range of $50 \%$.

2 The mechanized harvesting system was introduced in Brazil more than 30 years ago, but the obligatoriness is recent and has been progressive.
} 
commercialization of electricity produced by the sugarcane mills in the state of Mato Grosso do Sul, in the optic of transaction cost economics (TCE). The impact of the institutional environment on these governance structures was also evaluated, which allowed identifying necessary actions to improve production and favor the best arrangements.

TCE, developed by Williamson $(1985,1996)$ based on Coase's (1937) article, is the theoretical framework adopted to identify the most suitable institutional arrangements for the commercialization of electric energy generated from the pyrolysis of sugarcane biomass. This framework has already been used in many research on electricity (Finon \& Perez, 2007; Fabrizio, 2013; Signorini et al., 2015a; Delmas \& Tokat, 2005; Altman \& Johnson, 2008; Lopes \& Leite, 2016) or other energy sources (Ghosh \& Kathuria, 2015; Spanjer, 2009; Langniss \& Praetorius, 2006).

The relevance of this research is justified by the importance of the sugar and alcohol industry participation in the electricity supply to the Brazilian national interconnected system (SIN). Bioenergy complements the country's electricity supply in the period of the water deficit, as the sugarcane harvest occurs from April to December in the South, Southeast, and Midwest regions, a period coinciding with the lower water level in the hydroelectric reservoirs.

Also, sugarcane plants that inject electricity in the SIN are closer to the substations and consumption units, allowing the reduction of transportation costs and losses (Gomes \& Maia, 2013; Garcia et al., 2018).

Mato Grosso do Sul is the state where the sugarcane crop has grown the most in Brazil in the last ten years. Many areas with low productivity, mainly composed of degraded pasture lands, were recovered to produce sugarcane (Defante et al., 2018).

The next item addresses TCE, followed by the presentation of the institutional arrangements used in the electric sector. Item 4 presents the methodology used in the research and precedes the analysis of the institutional arrangements used in the commercialization of sugarcane electric energy in Mato Grosso do Sul. The last items of this work address the discussion of the results and the final considerations of the research.

\section{Transaction cost economics - TCE and renewable energy production}

It starts with a presentation of TCE before presenting some aspects related to renewable energy production.

\subsection{General aspects}

According to Williamson $(1985,1996)$, governance structures are the spot market, the hybrid forms, and the hierarchy. In the spot market, autonomous parties develop short-term relationships, taking the price as a thermometer for the interactions between them. At the other extreme is the vertical integration, in which the economic agents become part of the same entity, which facilitates the system coordination. Between the spot market and the vertical integration are located the hybrid forms, constituted of contractual relations in which the parts of the transaction are autonomous but have a bilateral relationship of dependency.

Although TCE analyzes these governance systems separately, some authors highlight the simultaneous presence of several systems in the same firm. In this case, with a set of solutions elected as the preferred, no arrangement seems to be efficient enough to be chosen alone in a particular transaction (Raynaud et al., 2019). These mixes of solutions are plural forms, organizational arrangements in which a part uses simultaneously different governance modes for the same activity and within the same institutional and competitive environment (Ménard, 2013). Schnaider et al. (2018) identified three types of plural forms, the "between" form, involving different organizational arrangements classes (make, buy, and hybrids) the "within" form, when a firm combines different hybrid arrangements modalities and the "combo" form, a mix of the "between" and "within" forms.

For TCE, in a particular type of institutional environment, the economic agents align governance structures with transactions to realize economies, especially transaction cost savings. Williamson (1996) affirms that the effectiveness of alternative governance structures 
varies according to the institutional environment, behavioral characteristics (limited rationality and opportunism), and transaction characteristics.

Transaction characteristics proposed by Williamson (1985 1996) are the asset specificity, the frequency of transactions, and uncertainty. Asset specificity is the most relevant attribute for the study of governance structures and is linked with the cost arising from the alternative allocation of an asset in another transaction. Williamson relates the degree of uncertainty of the transactions to the availability of information and the opportunistic behavior of individuals. In transactions, uncertainty makes it difficult to develop complete contracts, allowing gaps that allow opportunistic behavior. Frequency is related to the recurrence or regularity of transactions. The lower the frequency, the lower the agents' exposure to opportunistic behavior. On the other side, recurrent exchanges allow the development of compromises and reputation, limiting opportunistic behavior.

Ménard (2013) recognizes the importance of asset specificity as a determinant to the choice of governance systems. However, he considers a lower predictive power to explain hybrid governance and, mainly, plural forms. For the author, the adoption of plural forms can be explained by the complexity of transactions, mainly because of the type of investment needed or because of the uncertainties surrounding the transaction. Schnaider et al. (2018) also emphasize the role of uncertainty, in addition to the specificity of assets. For them, at intermediate levels of specificity, which should encourage companies to choose hybrid arrangements, the existence of some degree of uncertainty facilitates the adoption of plural forms. Raynaud et al. (2019) explain that underlying this theory is the idea that each arrangement complements the other to help deal with uncertain situations.

Schnaider et al. (2018) identified three types of uncertainty: market, technological and performance assessment uncertainties. The institutional environment is another aspect with significant influence on governance structures (Niesten et al., 2017), and that may be a source of uncertainty. For Ménard (2014), regulation and competition authorities had a direct impact. However, the mechanisms through which institutions shape and alter the organizational arrangements were not completely understood. But it is possible to estimate that an adequate regulatory design has institutional safeguards to prevent opportunistic behavior and tries to balance the trade-off between commitment (limiting governmental opportunism) and flexibility (Finon \& Perez, 2007; Ghosh \& Kathuria, 2015).

Following the definition of North (1990), Williamson considers institutions as the rules of the game. Changes in property rights, contractual laws, norms, and customs change the comparative costs of the modes of governance.

The social context in which transactions are embedded, defined among others by customs and habits, influences institutional arrangements, and must be considered. For Williamson (1985), the efficiency of alternative modes of governance varies in different cultures due to trust-related problems. Ménard (2004) also emphasizes the effect of reputation and experience. For the author, the effect of reputation is facilitated by the repetition of transactions between actors. Williamson (1996) reinforces the effect of experience and states that the institutional environment is the result of the actors' history.

Williamson (1996) identifies six attributes of embeddedness: social culture, politics, regulation, professionalization, networking, and culture. Those of greater interest for the research are the political and the regulatory insertions:

- Policy: legislative and judicial autonomy improves credibility (Williamson, 1996),

- Regulation: can serve to inspire confidence in business relationships. The creation and administration of a regulatory body are very significant acts.

The influence of these attributes is classified by Williamson (1996) as institutional trust (hyphenated trust). For the author, the need for safeguards for specific transactions (governance) varies according to the institutional environment in which transactions are embedded. Thus, viable transactions in an institutional environment that provide strong 
safeguards may be infeasible in weaker institutional environments. Since that is not safe for participants to make investments in specific assets in that situation.

Consequently, the quality of a judicial system is highly relevant. For Williamson (1996), in an economy in which the judiciary is problematic, institutional arrangements are more bimodal and focus on the spot market and vertical integration. North (2005) and Ménard and Shirley (2014) also mention the need to know who polices the state. For North (2005), how the game is played depends on the rules but also the effectiveness of enforcement of these rules. When institutions effectively restrain the opportunistic actions, they reduce the risk of holdup and ex-post expropriation by state actors, creating conditions under which firms are more willing to make sunk investments (Fabrizio, 2013; Henisz \& Zelner, 2001).

Thus, if property rights are subject to occasional reallocations and if the changes are not properly compensated, other strategic considerations enter into investment decisions. Lack of credible commitment on the part of the Government presents risks for durable and immobilized investments in the private sector. Transaction costs increase together with the risks of expropriation (Williamson, 1996).

The creation and administration of a regulatory body are very significant acts. With the presence of "appropriate" regulation, the parties involved in the transaction -the regulated company and its customers - are prepared to make investments in specific assets under better conditions than in the absence of such regulation (Williamson, 1999).

\subsection{TCE and the renewable electrical sector}

In the electric energy production from sugarcane biomass, Altman and Johnson (2008), and Signorini et al. (2015a) consider the physical asset specificity as an issue because of the difficulty to process other raw materials and the great financial commitments required. The locational specificity of the plants is also significant, as the processor is bound to trade with the local producers. Because of these specificities, long-term contracts are more attractive. However, for Langniss \& Praetorius (2006), these contracts limit the freedom of the involved parties.

The irreversibility of investments due to asset specificity creates regulatory risks and uncertainties. Thus, TCE provides a theoretical basis for understanding the regulatory intervention. The electricity sector markets can develop only when contracts are credible, complete, and have low opportunism risks (Ghosh \& Kathuria, 2015).

The frequency of transactions and uncertainty are the other attributes in Williamson's framework. As electricity is a good that is generated and consumed continuously, the transaction frequency is continuous (Signorini et al., 2015b). The uncertainty generally lowers investment, both in the short- and long-run. One particularly important form of uncertainty is regulatory or political uncertainty (Spanjer, 2009).

For Erdogdu (2013), the success or failure of a power market depends on whether a strong legal system clearly defines property rights and if the control structures for enforcing legislation and contracting arrangements exist.

Private investors in new generation capacities look for stable market rules and long-term contractual commitments. Once investors enter into contracts with buyers for power purchase, both parties are governed by the terms of the contract. Any change in these terms can impose high transaction costs, and unless the risks of such costs are minimized, either through a highly committed regulatory set-up or through long term contracts, the private investors will not enter into the generation of energy (Ghosh \& Kathuria, 2015).

The development and use of renewable energy depend on political and economic efforts that are directed by the State through regulatory and institutional instruments (Silva et al., 2013). For Nepal et al. (2014), the existence and experience of an independent regulator is the most important institutional determinant in electricity regulation. Praetorius and Bleyl (2006) mention that this regulator is important for tariff setting and investment decision-making criteria. Sander (2016) affirms that uncertainty motivates companies most often to look for increasing support by governments.

The following section presents the institutional arrangements used in the commercialization of electric energy in Brazil. 


\section{Institutional arrangements in the Brazilian electrical sector}

The rules of the Brazilian electricity sector were consolidated in the Law 10,847 (Brasil, 2004b) and Decree No. 5,163 (Brasil, 2004a). These rules were developed to meet the country's energy demand, favoring the entry of private capital investments in the energy generation sector.

\subsection{Structure of the Brazilian electrical sector}

The structure of the Brazilian electricity sector is hierarchical, represented in Figure 1. The Ministry of Mines and Energy (MME) is responsible for formulating policy adjustments for the energy sector. The National Electric Energy Agency (ANEEL) regulates and supervises the electric sector, ensuring the quality of the services provided, universal service, and establishing tariffs for final consumers. Below ANEEL, the National Electric System Operator (ONS) coordinates and controls the generation and transmission. The Electric Energy Trading Chamber (CCEE) is responsible for contract management, short-term market liquidation, and energy auctions.

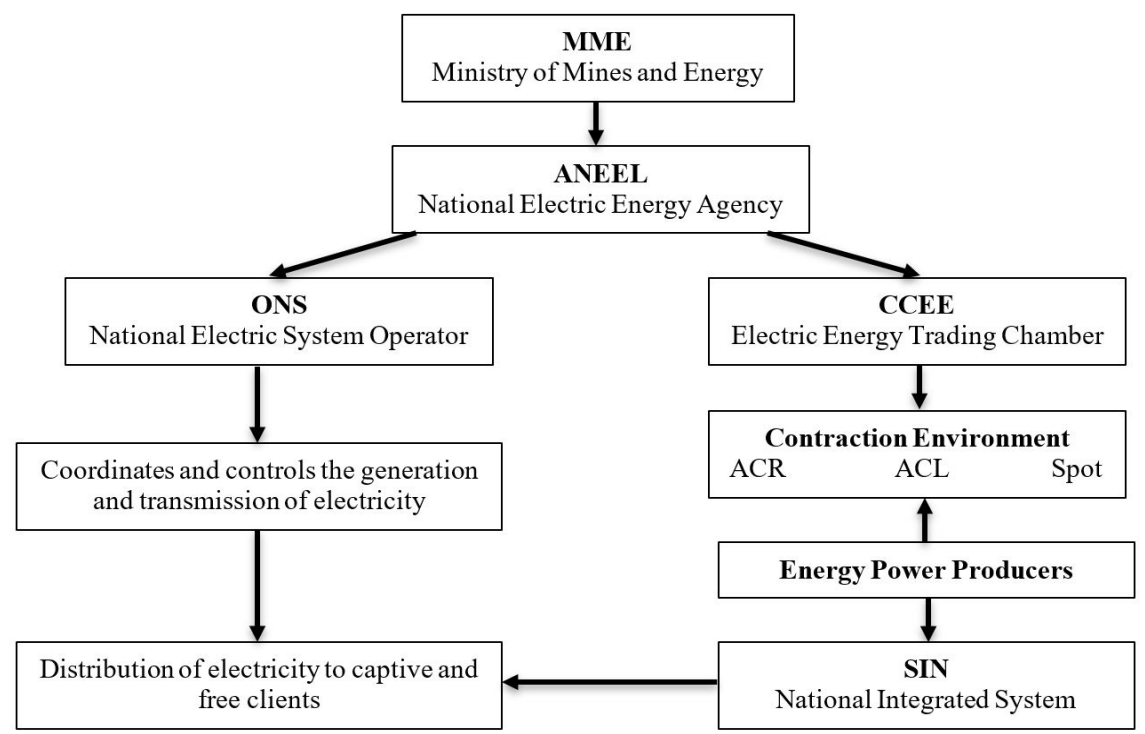

Figure 1 - Structure of the Brazilian electrical sector. Source: Carried out by the authors with CCEE data (Câmara de Comercialização de Energia Elétrica, 2020a, 2020b, 2020c)

The Brazilian energy matrix is diversified, with varied sources of energy generation (hydraulic, biomass, wind, photovoltaic, and others), with smaller projects alongside larger ones, being distributed in the various geographic regions of the country (Vahl et al., 2013), and increased private sector participation (Rego \& Parente, 2013).

In addition to the spot market, the commercialization of electricity is carried out by two models of contracts: the Regulated Contracting Environment (ACR), subjected to the rules established by the regulatory agency and government directives, and the free contracting environment $(A C L)$, which allows generators and traders to commercialize energy freely (Rendeiro et al., 2011).

\subsection{Regulated Contracting Environment (ACR)}

Concerning ACR, distribution agents can acquire energy in the following ways (Souza \& Legey, 2010; Câmara de Comercialização de Energia Elétrica, 2020a):

(a) Auctions for electricity purchase from existing generation projects as well as new generation projects. The institutional arrangements of this modality are formalized through the regulated bilateral contracts, known as energy trading agreement in 
regulated environment (CCEAR), concluded between selling agents (generation, commercialization, or import agents) and distributors. The purpose of these arrangements is carried out to create a market with long-term contracts (Hofsetz \& Silva, 2012; Câmara de Comercialização de Energia Elétrica, 2020a).

(b) Reserve power purchase auction. The energy supplied in this type of arrangement complements the amount contracted in the CCEAR. This form of contracting is formalized through Reserve Energy Contracts (CERs) between agents selling at the auctions and the Electric Energy Trading Chamber, as a representative of the consumer agents.

(c) Distributed Generation (DG) ${ }^{3}$ with contracting preceded by a public call is carried out by the distribution agent himself. This type of contract is limited to $10 \%$ of the total energy market of the distribution company.

(d) Contracts in the first phase of the Incentive Program for Alternative Energy Sources (PROINFA), with a duration of 20 years.

(e) Itaipu Binacional, in the case of distribution agents whose concession area is located in the South and Southeast regions of Brazil and in the state of Mato Grosso do Sul. The Law 5,899/73 obliges the concessionaires of these regions to buy a share of energy from Itaipu by cogent contract.

The bidding documents for bilateral agreements through CCEAR are opened under the national energy planning and in two modalities, existing energy, and new energy. The first corresponds to the production of companies already in operation, and the volumes contracted are delivered in a term of less than or equal to one year. The second concerns the production of units that have already been granted by ANEEL and are in the planning or construction phase. In this case, the deadline to start delivery is three to five years (Ursaia et al., 2013).

The distributors must declare to the Ministry of Mines and Energy (MME) the volumes to be contracted to cover all of their markets. With this information, the grantor determines the volume demanded in each auction. In addition to approve the amount of electricity to be contracted, MME approves the list of new generation projects that will integrate the bidding process (Câmara de Comercialização de Energia Elétrica, 2020b).

The maximum prices for energy acquisition in the auctions are defined by the MME, and according to the provisions of item VII of art. 20, of Decree No. 5,163 (Brasil, 2004a), the lowest bidding criterion is used to define the winners. At the end of the auctions, standardized bilateral contracts named CCEAR are signed between each seller and all concessionaires and authorized agents of the public distribution service (Câmara de Comercialização de Energia Elétrica, 2020b).

According to Law 10,848 (Brasil, 2004c), existing energy contracts have a duration of 1 to 15 years, while new energy contracts can last from 15 to 35 years. The Decree No. 6,048, dated February 27, 2007 (Brasil, 2007), regulated the auctions of renewable energy sources, biomass, and energy from Small Hydroelectric Power Plants (SHPP), with a term of 1 to 5 years to start, and with a duration of 10 to 30 years.

\subsection{Free contracting environment (ACL)}

The commercialization of energy in the free contracting environment is carried out through the purchase and sale of energy between the concession agents, traders, and importers of electricity, on the one hand, and the free or special consumers, on the other (Câmara de Comercialização de Energia Elétrica, 2020b).

All contracts negotiated in the ACL have their conditions of service, price, and other contractual clauses freely negotiated between the parties these contracts are called contracts for commercialization of energy in the free environment (CCEAL). Contracts signed in the ACL

\footnotetext{
${ }^{3}$ Distributed Generation (DG) is considered the production of electric energy coming from concessionaire enterprises connected directly to the electric distribution system of the buyer (Brasil, 2004a). This generation does not pass through transmission lines, destined for the transport of energy at greater distances.
} 
must be registered within the CCEE, following the provisions of art. 56 of the Decree No. 5,163 I 04 (Brasil, 2004a).

The free consumers are considered those whose contracted demand is equal to or greater than 3,000 kW, serviced at a supply voltage above $69 \mathrm{kV}$. These customers can acquire energy from any incentivized ${ }^{4}$ and/or conventional ${ }^{5}$ source (Souza \& Legey, 2010).

According to Coutinho \& Oliveira (2013), special consumers are those whose contracted demand is greater than or equal to $500 \mathrm{KW}$. These consumers can purchase only incentivized and special conventional energy. The contracts are called Agreements of Commercialization of Incentivized Energy (CCEI) and Contracts of Commercialization of Special Conventional Energy (CCECE).

The consumers who choose to become free, purchasing energy through ACL contracts, are subject to payment of all charges, fees, and sectorial contributions under the legislation. The generation agents can sell electricity in both environments (ACR and ACL) while maintaining the competitive character of the energy generation.

\subsection{Spot market}

All electricity contracts are registered at CCEE, which measures the amounts produced or consumed by each agent. The differences established are settled in the Short-Term Market, or spot market, at the Difference liquidation price, PLD, as indicated in Figure 2 (Câmara de Comercialização de Energia Elétrica, 2020a, 2020b).

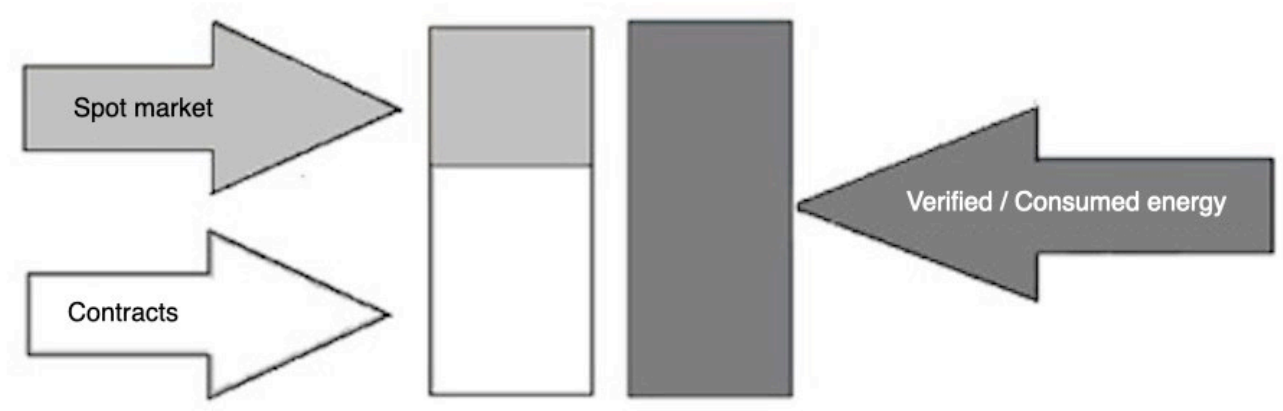

Figure 2 - Measurement of the amounts produced/consumed by each agent and the differences between the energy produced and consumed. Source: Authors, with data from Câmara de Comercialização de Energia Elétrica (2020a, 2020b).

To commercialize electricity in the spot market, the agents must inject the energy produced into the SIN, which is accounted for by CCEE. The CCEE performs three tasks: I - manages all contracts for the purchase and sale of energy, II - records the daily measurement of what is generated in the plants and consumed by all agents participating in the system, and III - accounts for amounts payable and receivable based on the purchase and sale agreements and effective generation and consumption (Câmara de Comercialização de Energia Elétrica, 2020a, 2020b).

The PLD is determined weekly for each load level, limited by maximum and minimum prices, and is used to value the energy not contracted among the CCEE agents (surplus or difference) in the spot market (Araujo et al., 2008; Câmara de Comercialização de Energia Elétrica, 2020b). The PLD reflects the marginal cost of the new electricity in the system. In the rainy season, when the supply and demand for electricity in the country are balanced, the price of electric power is lower, as is, consequently, the PLD. When the water reservoirs are

\footnotetext{
${ }^{4}$ Incentivized source: Renewable energy generation projects with an installed capacity of not more than $30 \mathrm{MW}$, such as wind power plants, biomass thermal plants, and solar power plants, as well as hydroelectric generating plants that have a capacity equal to or less than $1 \mathrm{MW}$ (Coutinho \& Oliveira, 2013). This energy has a reduction of at least $50 \%$ in the Tariffs for the Use of Electric Transmission and Distribution Systems (TUST and TUSD) (Brasil, 2006).

${ }^{5}$ Conventional source: hydroelectric or thermoelectric plants with installed power above $50 \mathrm{MW}$ and renewable energy companies with an installed capacity between 30 and 50 MW (Special Conventional Energy).
} 
low, there is a lack of energy, and the thermal plants are linked to a high marginal cost, pushing up the energy price and the PLD (Dalbem et al., 2014).

The crisis in the Brazilian electricity supply, which occurred due to climate issues and the lack of planning and investments by the Federal Government, caused a large increase in the PLD. From December 2013 to April 2014, the value of the PLD in the Southeast / Midwest sub-market increased from R $\$ 290.72$ (US \$ 125) to R\$ 822.83 (around US \$ 369) per megawatt-hour (MWh), with the maximum price stipulated by ANEEL. This increase occurred due to the greater activation of thermoelectric plants caused by the low level of hydroelectric reservoirs. In March 2015, the value of the PLD dropped to R $\$ 388.48$ (US $\$ 121.40$ ), the new ceiling set by CCEE. In October of the same year, the value was $R \$ 212.32$, after a minimum of $R \$ 145.09$ in August.

\section{Research methodology}

This study focuses on the sector of renewable energy from sugarcane biomass in the state of Mato Grosso do Sul, between the years 2015 and 2016. In this period, the state represented $7.7 \%$ of the Brazilian sugarcane production (União da Industria de Cana de Açúcar, 2018), and more than $10 \%$ of the total power produced with sugarcane biomass in Brazil, which puts Mato Grosso do Sul as the second-largest producer, behind the state of São Paulo (União da Industria de Cana de Açúcar, 2017).

In the state of Mato Grosso do Sul, in 2016, there were twenty-two sugar-alcohol units in activity, with half of them commercializing electricity. The state can be considered an extension of the state of São Paulo, which produces more than half of the national sugarcane production. The lack of land in São Paulo forced the expansion of the sector in other states, mainly Mato Grosso do Sul. From 2006 to 2016, the increase of sugarcane production was 52\% in Brazil and 332\% in Mato Grosso do Sul (União da Industria de Cana de Açúcar, 2018). The main Brazilian sugarcane companies are present in the state, where they adopt strategies similar to those adopted in the state of São Paulo.

As for Signorini et al. (2015b), the present study used an extensive literature review and key informant interviews. Interviews with specialists have been realized in 2015 in the Mato Grosso do Sul Bioenergy Producers' Association (BIOSUL), in the Mato Grosso do Sul energy concessionaire (ENERGISA), which distributes more than $90 \%$ of the electric energy consumed by the inhabitants of the state, and at the State Technical Chamber of Electric Power (CATENE) and Dedini S/A, the largest Brazilian manufacturer of boilers and equipment for the sugar and alcohol industry. These interviews were semi-structured and allowed a better understanding of the commercialization of renewable energy in the state, and of the energy production from sugarcane biomass.

At BIOSUL, the interview was held with the person responsible for the verification of the state production of energy from sugarcane biomass in order to clarify the energy scenario of the sugar and alcohol industry. At ENERGISA, the interview was carried out with the coordinator of the large customers to clarify the operation of the energy contracts. At CATENE, the interview was performed with the President concerning the transactions in the energy sector in the state. At Dedini, the interviews have been conducted with the person responsible for the boiler department to obtain information on boilers and the equipment that composes the power generation plants. In the case of Dedini, in the state of São Paulo, the interview was conducted by telephone. The other interviews were all done at the companies' place.

After the interviews with the specialists, which allowed a better knowledge of the researched subject, data from industry were collected from a series of structured interviews in four production units located in the region of Dourados, the center region of Mato Grosso do Sul State. These interviews were conducted in the production units, at the end of 2015, in which the industrial directors and the coordinators of the generation sector were interviewed. The visits allowed deeper access to information with an explanation on investments, used governances for power commercialization and obtainment of bagasse for power production. It was possible to document the technologies used for the transformation of thermal and mechanical energy into electric energy.

At the beginning of 2016, telephone contacts were made with the industrial directors of the other 18 units in activity in Mato Grosso do Sul, and questionnaires were 
sent to all of them. The average response rate was $70 \%$, with $100 \%$ of the units that commercialize electric energy in the state. The questions covered the same information as in the interviews with the managers of the 4 mills near Dourados: I - Installed grinding capacity of the plant II - Capacity used by the plant III- Number of boilers installed IV Percentage of bagasse and straw that is burned Purchase of bagasse Recovery of straw V- Quantity and percentage of energy produced per crop and sold to the regulated market VI- Commercialization of electric energy in the free and spot markets. This information is important to identify the existence of specific assets, uncertainty, and frequency of transactions in electric energy production, as well as the institutional arrangements used for the commercialization of the energy.

In the end, all the necessary information was obtained from the 12 sugarcane plants with the commercialization of electricity in Mato Grosso do Sul, and from a unit that was in the final stage of investment to commercialize this type of energy. Four sugarcane mills without electricity commercialization also answered the questionnaire.

After the application of the questionnaires, the announcements of the energy auctions from 2004, the date of the first auctions based on the Decree No. 5,163 of July 30, 2004 (Brasil, 2004a), until December of 2015, were consulted, as well as the rules for the commercialization of all modalities of contracts for the year 2015. All the auctions made during this period have been consulted in Câmara de Comercialização de Energia Elétrica (2015).

With all this information, complementary telephone interviews were carried out with six of the sugarcane mills with energy commercialization. These interviews, conducted with the managers of the electricity generation sector, were aimed at ascertaining the market and the energy contracts and what were the future expectations. In addition to these contacts, an interview was conducted with a former director of the São Martinho group, the fourth-largest sugarcane processor in Brazil. This interview had the purpose of validating the results obtained in the research and verifying their applicability for the other production states.

The data collected allowed to identify the institutional arrangements adopted by the sugar and ethanol plants for the commercialization of electricity and to verify the adequacy of these arrangements with the characteristics of the transactions raised by TCE: asset specificity, frequency, and uncertainty. The information was tabulated in an Excel spreadsheet to facilitate the analysis, gathering the answers of questionnaires and the synthesis of the energy auctions.

The Federal Government's role in organizing the arrangements and in the investment decisions of the sugarcane processing companies was also evaluated from the interviews with the specialists (CATENE, BIOSUL, ENERGISA).

\section{Results and discussion}

The analysis describes the characteristics of the institutional arrangements in the commercialization of electricity by sugarcane mills in Mato Grosso do Sul, and the impact of institutions on the uncertainty in the sector.

\subsection{Electrical power of sugarcane biomass in Mato Grosso do Sul}

According to Associação dos Produtores de Bioenergia de Mato Grosso do Sul (2015), in 2015 , the installed capacity of the sugar and alcohol units in Mato Grosso do Sul was 60 million metric tons of sugarcane per harvest. The analysis of the questionnaires indicates that these units had an average idle capacity of $20 \%$.

Figure 3 shows the electricity supply by the sugar and alcohol industry in the SIN that began in the 2009/2010 harvest. The commercial electricity delivered by the sugar and alcohol industry of Mato Grosso do Sul in the $2016 / 17$ harvest was 2,718 GWh, more than $10 \%$ of the electricity produced with sugarcane biomass in the same period in Brazil (Associação dos Produtores de Bioenergia de Mato Grosso do Sul, 2019; União da Industria de Cana de Açúcar, 2017). 


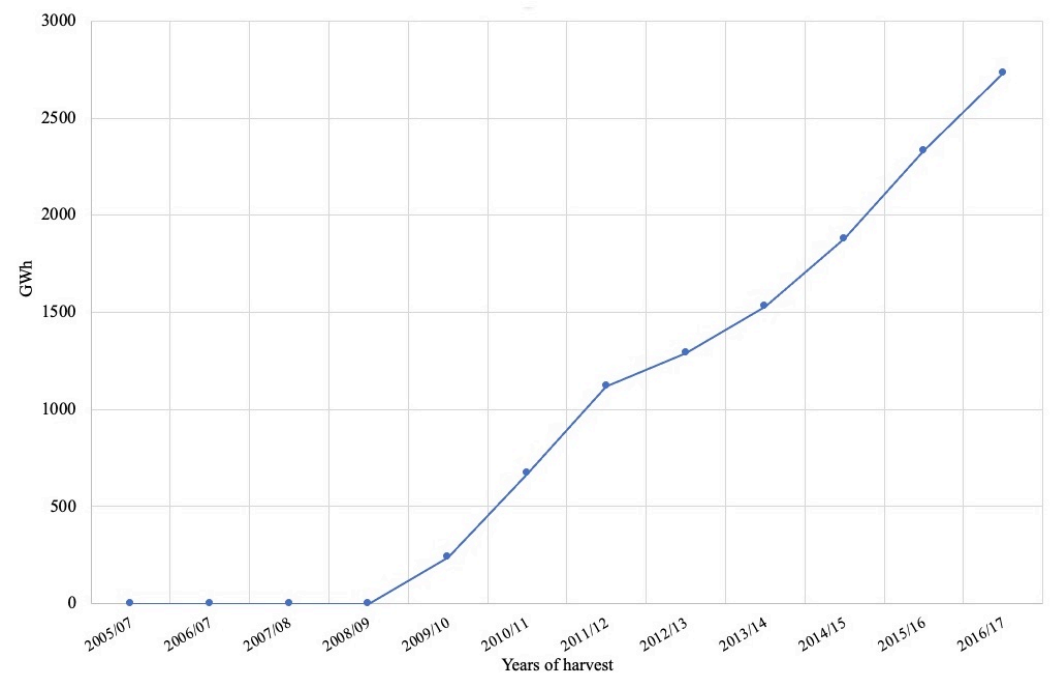

Figure 3 - Electric energy sold by the sugarcane plants of Mato Grosso do Sul, in GWh, between the 2005/2006 and 2016/17 harvests. Source: Associação dos Produtores de Bioenergia de Mato Grosso do Sul (2015, 2019).

With the fluctuation of sugar and ethanol prices, the sugar and alcohol units invested in the generation of electricity to diversify their economic return. To make the process more efficient, innovative technologies with greater efficiency in electric energy production, such as fluidized bed boilers, have been adopted by the sugarcane plants (Bocci et al., 2009).

The information obtained from the interviews indicated that the electricity market in the 2014/15 harvest allowed for significant economic returns. In the months of high-energy consumption, the economic return from the commercialization of electricity was higher than that provided by ethanol and sugar. Due to the potential of electric power commercialization, the sugarcane units already in this market are opting to increase their electricity production, as indicated in Figure 3.

To take full advantage of the installed capacity of the generating plant, all units that sell electricity declared that they burned all the bagasse produced in 2014 and 2015, maintaining only a reserve to start the following harvest. One of the sugarcane plants reported that it burned all the bagasse and collected the straw to boost the production of electricity that same year. Besides burning all the bagasse generated, another plant carried out an internal bagasse transfer from the units of the group that did not commercialize their energy.

\subsection{Institutional arrangements for the commercialization of energy from sugarcane}

The bidding documents and the electric energy transactions are available on the CCEE website. Have been highlight those in which units from Mato Grosso do Sul participated from 2004, the beginning of the auctions in ACR, until December 2015. The results are presented in Table 1.

As indicated in Table 1, Biosev, belonging to the Louis Dreyfus Company, was the first to sign ACR contracts in 2007 through a New Energy Auction (LEN), with a three-year term to start. In 2010, other units entered the market, with LEN of three (A-3) and five (A-5) years to start the supply, and with Reserve Energy Auctions (LER), aiming to increase the national security of the electricity supply.

All the commercialization through the LER and LEN contracts of A-3 were for 15 years, while the marketing in LEN of A-5 was always for 25 years. The prices negotiated in ACR are readjusted annually by the Extended Consumer Price Index (IPCA) (Agência Nacional de Energia Elétrica, 2015b). In the last auction of 2015, the Existing Energy Auction - LEE 15/2015, the sugar and ethanol units entered the existing energy market with sales contracts beginning in January 2016 and lasting only three years. Three companies located in Mato Grosso do Sul sold energy at this auction. The shorter duration of these contracts did not increase the uncertainty of the companies, since they already had new or reserve energy contracts (LEN and LER), with a duration of 15 and 25 years, respectively. 
Table 1 - Transactions carried out by the Mato Grosso do Sul sugar-ethanol thermoelectric plants from 2004 to 2015.

\begin{tabular}{|c|c|c|c|c|c|c|}
\hline Group & Unit & Municipality & $\begin{array}{c}\text { Auction } \\
\text { announcements* }\end{array}$ & $\begin{array}{l}\text { Contracts } \\
\text { duration } \\
\text { (Years) }\end{array}$ & $\begin{array}{l}\text { Power } \\
\text { rating } \\
\text { (MW) }\end{array}$ & $\begin{array}{c}\text { Price } \\
\text { (R\$/MWh) }\end{array}$ \\
\hline Biosev & LDC Bioenergia S/A-I & Rio Brilhante & 01/2007 - LEN A-3 & 15 & 50.0 & 139.12 \\
\hline Biosev & LDC Bioenergia S/A - II & Rio Brilhante & 01/2007 - LEN A-3 & 15 & 50.0 & 139.12 \\
\hline Odebrecht & Usina Eldorado S.A & Rio Brilhante & 05/2010 - LER & 15 & 12.0 & 154.25 \\
\hline Bunlai/Bertin & São Fernando Energia I & Dourados & 05/2010 - LER & 15 & 50.0 & 154.40 \\
\hline Adecoagro & Angélica Agroenergia Ltda. & Angélica & 05/2010 - LER & 15 & 64.0 & 154.25 \\
\hline Grendene/Shimith & IACO Agrícola S/A & Chapadão do Sul & 02/2011 - LEN A-3 & 15 & 30.0 & 101.99 \\
\hline Biosev & LDC - Bioenergia S.A. p.t & Rio Brilhante & 02/2011 - LEN A-3 & 15 & 64.8 & 103.29 \\
\hline Grendene/Shimith & IACO Agrícola S/A & Chap. do Sul & 03/2011 - LER & 15 & 30.0 & 101.49 \\
\hline Adecoagro & Angélica Agroenergia Ltda & Ivinhema & 16/2013 - LEN A-5 & 25 & 40.0 & 135.00 \\
\hline Odebrecht & Usina Eldorado S.A & Rio Brilhante & 16/2013 - LEN A-5 & 25 & 116.0 & 132.30 \\
\hline Coutinho & Santa Helena & Nova Andradina & 16/2013 - LEN A-5 & 25 & 45.0 & 132.81 \\
\hline Cosan/Shell & Raízen & Caarapó & 16/2013 - LEN A-5 & 25 & 38.0 & 134.37 \\
\hline Tonon & Unidade Vista Alegre II & Maracaju & 18/2013-LEN A-5 & 25 & 30.0 & 133.00 \\
\hline Tonon & Vista Alegre I & Maracaju & 18/2013 - LEN A-5 & 25 & 30.0 & 133.01 \\
\hline Odebrecht & Usina Eldorado S.A & Rio Brilhante & 15/2015 - LEE A-1 & 3 & 141.0 & 165.50 \\
\hline Odebrecht & Santa luzia I & Nova Alvorada & 15/2015 - LEE A-1 & 3 & 130.0 & 163.00 \\
\hline Adecoagro & Angélica Agroenergia Ltda. & Ivinhema & 15/2015 - LEE A-1 & 3 & 120.0 & 161.29 \\
\hline
\end{tabular}

Legend: (*) LEN - New Energy Auction LER - Reserve Power Auction LEE - Existing Energy Auction. Source: Câmara de Comercialização de Energia Elétrica (2015)

In the contracts from 2010, the offered prices varied from 139 to $154 \mathrm{R} \$ / \mathrm{MWh}$, values higher than the PLD of the same year, which was R\$70. In 2011, the contracts were sealed with prices of approximately $100 \mathrm{R} \$ / \mathrm{MWh}$, higher than the average PLD of the same year, which was less than $\mathrm{R} \$ 30$. In 2013, the auctions were closed with prices from 132 to $135 \mathrm{R} \$ / \mathrm{MWh}$, this time lower than the average PLD of the year, which was $\mathrm{R} \$ 262.5$. In 2015 , the auction prices were lower than the average PLD of November 2015, which was 202.87 R\$/MWh.

Table 1 does not present the values related to electric energy sold by the Monte Verde Plant, which uses the ACL. This plant has an installed capacity of $20 \mathrm{MW}$ and commercializes the electric energy produced to the Bunge group, to which it belongs.

The electric energy of sugarcane biomass marketed in Mato Grosso do Sul in the 2014/15 harvest was $1,879 \mathrm{GWh}$, of which $64 \%$ was sold through CCEARs. The other $36 \%$ of the biomass energy marketed in the state represented, in the 2014/15 harvest, 676.44 GWh. Approximately 200 GWh of this energy were negotiated with the local concessionaire in the form of Distributed Generation (10.6\% of the total), and $50 \mathrm{GWh}$ for special consumers in the ACL ( $2.7 \%$ of the total). The other $426.44 \mathrm{GWh}$, or $22.7 \%$ of the state's total production, were traded on the short-term or spot market.

The commercialization for special consumers was conducted between companies of the same group. In the case of commercialization in Distributed Generation, the 
commercialization contract is 25 years. Table 2 presents the different institutional arrangements adopted by sugarcane processing units for energy commercialization. It should be noted that only one unit concentrates on only one type of arrangement, contracts in the ACR for new energy (LEN). The Santa Helena plant was not yet providing electricity in 2016, which explains the absence of this company in the spot market and the use of only one type of arrangement. All the others divide commercialization into different types of arrangements. A Biosev unit also uses one type of arrangement, but the other unit of the same group uses other arrangements, such as the spot market and ACR for new energy.

Table 2 - Modalities of the contracts made by the sugar and alcohol industry units.

\begin{tabular}{|c|c|c|c|c|c|c|c|}
\hline \multirow{2}{*}{ Unit } & \multicolumn{4}{|c|}{ ACR } & \multirow{2}{*}{ ACL } & \multirow{2}{*}{$\begin{array}{c}\text { Spot } \\
\text { market }\end{array}$} & \multirow{2}{*}{$\begin{array}{l}\text { Plural } \\
\text { form }\end{array}$} \\
\hline & LEN & LER & LEE & DG & & & \\
\hline Adecoagro - Angélica & & $x$ & & & & $x$ & Combr \\
\hline Adecoagro - Ivinhema & & $x$ & $x$ & & & $x$ & 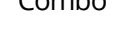 \\
\hline Biosev - Rio Brilhante - Unit of Passa Tempo & $x$ & & & & & $x$ & Between \\
\hline Biosev - Rio Brilhante & $x$ & & & & & & Detween \\
\hline Bunge - Ponta Porã & & & & & $x$ & $x$ & Between \\
\hline laco - Chapadão do Sul & $x$ & & & & & $x$ & Between \\
\hline $\begin{array}{l}\text { Odebrecht - Rio Brilhante, Costa Rica \& Nova } \\
\text { Alvorada }\end{array}$ & $\mathrm{x}$ & $x$ & $x$ & & & & Within \\
\hline Raízen - Caarapó & $\mathrm{x}$ & & & & & $x$ & Between \\
\hline São Fernando - Dourados & & $x$ & & & & $x$ & Between \\
\hline Tonon - Vista Alegre - Maracaju & $x$ & & & $\mathrm{x}$ & & $x$ & Combo \\
\hline Santa Helena & $x$ & & & & & & Hybrid \\
\hline
\end{tabular}

Legend: $X$ = Type of arrangement used LEN - New Energy Auction LER - Reserve Power Auction LEE - Existing Energy Auction DG - Distributed generation. Source - Data from Câmara de Comercialização de Energia Elétrica (2015) and sugarcane mills

After ensuring their self-sufficiency, the priority of the sugarcane processing plants is to produce energy to meet the contracts, either in the ACR or in the ACL. The electricity sold to the spot market is the energy left over. When the price paid in the spot market pays off, the sugar and ethanol plants buy bagasse or wood chips to produce more energy and sell it in this market.

Data from Câmara de Comercialização de Energia Elétrica (2015), the interviews and questionnaires applied in the sugarcane mills, indicated the use of a mix of governance systems in the commercialization of electricity in all companies:

- Hybrid arrangements: use of formal contracts in different markets:

- Regulated market: the most used by the companies, with a mix of long-term contracts, such as new and reserve energy (LEN and LER) and Distributed Generation (DG), and short-term contracts, in the case of existing energy (LEE)

- Free market: private marketing contracts between two companies, which were from the same company in the evaluated case.

- Spot market: used by all the companies that commercialize energy, complementing the hybrid arrangements.

These mixes of arrangements are plural forms, as defined by Ménard (2013). According to the classification of Schnaider et al. (2018), the three types of plural forms were found the "between", "within" and "combo" forms, with the first being the most frequent. For the classification, it was considered the LEN and LER contracts as similar hybrid forms, as they have the same characteristics. The LEE and DG contracts were considered separate hybrid arrangements, although they also belong to the ACR. 


\subsection{Characterization of the electric energy transactions}

Energy transactions are continuous, as mentioned by Signorini et al. (2015a), but the sale in ACR or the spot market does not involve direct contact between suppliers and buyers, who do not need to know each other. It makes it impossible to develop trust relationships, which typically occurs in repeated and frequent transactions. These markets are controlled by CCEE and there is no need for trust between buyers and suppliers.

In contrast, ACL contracts do not receive assistance from CCEE to cope with uncertainty exposure. Complexity has a higher level of importance for trading parties as they must identify counterparties, write formal agreements, negotiate safeguards, and monitor agreement performance (Signorini et al., 2015b). However, the high frequency of relationships and direct contacts between suppliers and buyers make it possible to develop trust relationships. As found in the research, contracts between units of the same group allow to raise confidence levels and to reduce risks.

Despite the absence of contracts, the spot market is also controlled by CCEE. In this case, there is no need for trust between buyers and suppliers but reliability concerning the regulatory institutions. This aspect will be addressed in Item 5.4 of this article, which contemplates the uncertainty in the transactions.

Asset specificity is considered the most important characteristic of transactions identified by Williamson (1985). The boiler is the main item of the equipment necessary for the commercialization of electric power. What distinguishes the sugar-alcohol units that commercialize energy are the high-pressure boilers, from 67 to 100 bars, with a generation of 150 to 400 metric tons of steam per hour, which provides sufficient capacity to generate electricity surplus (Table 3). On the other hand, the boilers of companies that produce energy only for their use generate steam of 21 bars and approximately 60 metric tons of steam per hour.

Table 3 - Installed capacity of the boilers in the sugar and ethanol thermoelectric units of Mato Grosso do Sul.

\begin{tabular}{|c|c|c|c|c|c|}
\hline \multirow[b]{2}{*}{ Units } & \multirow[b]{2}{*}{ Localization } & \multicolumn{4}{|c|}{ Types of boilers } \\
\hline & & Brand/model & $\begin{array}{c}\text { Flow rate } \\
\text { t.s./h* }\end{array}$ & $\begin{array}{c}\text { Operating } \\
\text { pressure (bar) }\end{array}$ & $\begin{array}{c}\text { Steam } \\
\text { Temperature } \\
\left({ }^{\circ} \mathrm{C}\right)\end{array}$ \\
\hline \multicolumn{6}{|c|}{ Commercialization of electric energy } \\
\hline \multirow{2}{*}{ Adecoagro } & \multirow{2}{*}{ Angélica } & HPB VS 500 & 250 & 67 & 490 \\
\hline & & HPB VS 500 & 250 & 67 & 490 \\
\hline \multirow{2}{*}{ Adecoagro } & \multirow{2}{*}{ Ivinhema } & HPB VS 500 & 320 & 67 & 520 \\
\hline & & HPB VS 500 & 200 & 67 & 480 \\
\hline Biosev & Rio Brilhante & HPB VS 5250 & 250 & 67 & 490 \\
\hline Biosev & Rio Brilhante & HPB VS 5250 & 250 & 67 & 490 \\
\hline Bunge - Monte Verde & Ponta Porã & Dedini AZ 200 & 150 & 67 & 490 \\
\hline \multirow{2}{*}{ São Fernando } & \multirow{2}{*}{ Dourados } & HPB VS 500 & 250 & 100 & 540 \\
\hline & & HPB VS 500 & 250 & 100 & 540 \\
\hline Raízen & Caarapó & Dedini AT 275 & 275 & 65 & 515 \\
\hline \multirow{2}{*}{ IACO Agrícola S/A } & \multirow{2}{*}{ Chap. Sul } & HPB VS 500 & 210 & 67 & 515 \\
\hline & & HPB VS 500 & 210 & 67 & 515 \\
\hline Odebrecht & Costa Rica & HPB & 200 & 67 & 490 \\
\hline \multirow{2}{*}{ Odebrecht } & \multirow{2}{*}{ Rio Brilhante } & HPB-BFB & 400 & 100 & 540 \\
\hline & & Dedini & 200 & 42 & 400 \\
\hline \multirow{2}{*}{ Odebrecht } & \multirow{2}{*}{ Nova Alvorada } & HPB & 260 & 67 & 500 \\
\hline & & HPB & 320 & 67 & 520 \\
\hline Tonon - Vista Alegre & Maracaju & HPB - VS 500 & 250 & 67 & 490 \\
\hline \multicolumn{6}{|c|}{ Energy only for own use } \\
\hline \multirow{3}{*}{ Santa Helena Unit } & \multirow{3}{*}{ Nova Andradina } & Zanini - SZ-180 & 60 & 21 & 320 \\
\hline & & Zanini - SZ-180 & 60 & 21 & 320 \\
\hline & & Dedini 600/6T & 130 & 21 & 320 \\
\hline
\end{tabular}

Legend $\left(^{*}\right)$ t.s./h - metric tons of steam per hour. Source - Authors. 
According to the Dedini Company, the average amount of investment to produce electric energy from sugarcane bagasse varies from 4.5 to 5.0 million reais (1.4 to 1.6 million dollars) for each MWh of installed capacity.

The boiler is the equipment that requires more investment but other necessary equipment, such as handling and storage systems, turbines, generators, transformers, and transmission networks, are also expensive. Information provided by one of the sugar-ethanol units that commercialize electricity in Mato Grosso do Sul indicates that the investments in basic generation plant equipment exceed 100 million reais (Table 4), a cost that represents 25 to $30 \%$ of the total cost of a production unit.

Table 4 - Average cost of investments for production and commercialization of electric energy with a capacity of $48 \mathrm{MWh}$.

\begin{tabular}{cc} 
Type of boiler & Average cost \\
\hline $\begin{array}{c}\text { Operating pressure }(\mathrm{Kgf} / \mathrm{cm}): 67 \\
\text { Capacity }(\mathrm{Kg} / \mathrm{h}): 210 \mathrm{t} \\
\text { Steam temperature: } 515^{\circ} \mathrm{C} \\
\quad \text { Turbine + generator }\end{array}$ & $\mathrm{R} \$ 50.000 .000,00$ \\
Power transformers & $\mathrm{R} \$ 25.000 .000,00$ \\
Transmission network per kilometer & $\mathrm{R} \$ 20.000 .000,00$ \\
\hline
\end{tabular}

Source - Authors, based on information of Dedini Company.

The high values of the investments required to generate electric energy from biomass, the difference in equipment between a plant that sells and another that only generates for own use, and the difficulty of relocating this equipment in another unit are all indicators of a high degree of asset specificity, essentially of physical assets. This feature increases the need for guarantees for the proper functioning of the transactions.

Despite the high initial investment, the equipment can be easily depreciated with time because of its great durability. The boilers can work for 50 years, and generators can last over 100 years with maintenance every five years. Thus, long-term contracts offer the guarantee of being able to depreciate the investment over time.

The straw is another fuel that can be used. The straw recovery requires specific equipment for preparation and transport to the generation plant. If resold, this equipment loses value, which also characterizes the specific physical assets. However, the use of sugarcane straw is still a controversial issue. The most fertile soil can be mechanically removed along with the straw, increasing the incidence of mineral impurities in the chopped sugarcane.

According to Michelazzo \& Braunbeck (2008), sugarcane units can also harvest the whole plant, where the straw is harvested along with the stems, with the harvesters operating with extractors regulated to allow this material to pass. In this case, the system used requires a Dry Sugarcane Cleaning System (SLCS). This equipment is already used when the sugarcane is mechanically harvested, even without recovery of the straw, and does not characterize a specific investment.

Considering the high level of asset specificity, long-term governance structures were expected, as mentioned by Altman \& Johnson (2008), Signorini et al. (2015a), and Langniss \& Praetorius (2006). Although numerous empirical tests have shown the strong explanatory power of asset specificity as a determinant of the governance structures, Ménard (2013) considers that the predictive power is less convincing for plural forms of arrangements. The coexistence of different governance structures for the same type of transaction within the same firm is still a major puzzle and has not been studied enough (Lopes \& Leite, 2016). 


\subsection{Uncertainties in the commercialization of electric energy from sugarcane biomass}

Although Ménard (2013) considers the uncertainty important in explaining plural forms, Schnaider et al. (2018) are the ones who emphasized the role of this factor in the adoption of plural arrangements.

The main uncertainties that can influence the decision to commercialize biomass power are essentially related to the institutional environment, with a focus on the political and regulatory attributes, as discussed by Williamson (1996). Under conditions of asset specificity, the perception of regulatory instability restrains firm investments. Firms will be less willing to invest in specific assets when they perceive that future regulatory changes could reduce the value of those assets (Fabrizio, 2013).

Even if the autonomy of the judicial system does not seem to be a problem in Brazil, judicial decisions can have a great impact on the investment decision.

Due to the drought in the Southeast of Brazil in 2014 and 2015, many hydroelectric plants did not obtain enough energy to honor their contracts and had to supplement their production in the spot market. However, while the contract price was approximately $200 \mathrm{R} \$ / \mathrm{MWh}$, the average purchase price in the PLD was 689, reaching 822.83 part of the year, which caused significant losses to the hydroelectric plants.

In the meanwhile, sugarcane power units were producing more energy than they needed to honor their contracts and marketed the surplus on the spot market. This commercialization was a guarantee of high economic returns for the sugarcane companies, complementing the long-term contractual market. However, hydroelectric plants filed a lawsuit alleging the lack of production due to climatic issues. Since the end of 2015, the hydroelectric plants have achieved numerous judicial injunctions allowing the non-payment of the value due in the spot market. As a result, the sugarcane companies did not receive part of the payment for the energy in that market. For Souza (2017), at the end of 2017, the hydroelectric plants had a total of 4.3 billion reais unpaid, and with injunctions in court. Payment problems on the spot market continued after the end of the drought period and had not yet been solved in early 2019.

The action of justice to solve the problems of the hydroelectric plants directly affects the results of the sugarcane mills. The spot market transactions become risky, reducing the incentive to produce energy for this market. Consequently, the use of plural forms could be impaired, leaving only hybrid arrangements and the "within" plural form, which diminishes the financial return of companies and may jeopardize risk mitigation strategies. Thus, the judicialization in the spot market may lead to a reduction of the incentives in the production of energy from the biomass of sugarcane. As mentioned by Higashi et al. (2017), plural forms allow for a strong association of different governance systems, canceling out the eventual weaknesses present in each governance structure when used individually.

The legislative system and the regulatory agencies may also have a great influence on the decision to produce energy from sugarcane biomass. Both of them are subject to the influence of the Federal Government, showed in the Provisional Measure 579, of September 11, 2012, regulated by Decree No. 7.805, dated September 14, 2012 (Brasil, 2012). This measure obliged hydroelectric plants whose remaining concession term was equal to or less than sixty months, to apply for an extension before October 15, 2012. Failure to comply with the deadline resulted in the termination of the concession after its end. While the companies that fulfilled the deadline could have their contracts extended for another 30 years. Concerning the new contracts, the quantity of supply and prices were defined by the granting authority, reducing the prices charged before renewal.

This renewal was an evident intervention of the Federal Government, which forced the companies to quit their former contracts to oblige the reduction of prices and increase production. However, the renegotiation was carried out with the companies only at the end of their contracts and did not affect the generating units of sugarcane biomass, all of them with recent contracts. Moreover, the plural form of arrangements in the electricity sector from sugarcane biomass reduces the impact of government interference, even if the judicialization in the spot market can undermine the efficiency of this system. Contracts of new and reserve energy provide long-term security, which is necessary because of the asset specificity but does 
not protect against Government interference, differently of $A C L$ and Distributed Generation contracts. This quest for security may explain why in 2016 the ACR contracts fell $2 \%$, while the ACL contracts increased by $6.6 \%$ compared to 2015 (Associação Brasileira de Comercializadores de Energia, 2017).

Another impact of Government action was the reduction of the PLD ceiling from $R \$ 822.83$ in 2014 to $R \$ 388.48$ per MWh in 2015. The fixing of a limit price in the spot market prevents the price from fluctuating due to supply and demand and may further limit the importance of the spot market for sugarcane mills.

\section{Conclusion and Policy Implications}

The difference between the potential and the production of energy from sugarcane biomass in Brazil may be explained by the high investments in specific physical assets, with investments that may exceed $25 \%$ of the total value of the plant, a high value for many companies. The high specificity of the investments required for the commercialization of electric energy from sugarcane biomass increases the sensitivity of the sugarcane mills to uncertainty.

The judicialization of the spot market and the interference of the Federal Government may cause significant uncertainty in the sector of electrical power. As a consequence, the investments could be below the potential of the industrial sector, which may answer the question presented in the Introduction section on why half of the state's production units did not enter this activity.

The development of the plural forms may be explained by uncertain situations, such as the fragility of the institutional environment. In the Brazilian electrical market, the fragile institutional environment is responsible for the ambiguity regarding the advantages associated with the different modes of governance, leading companies to adopt plural forms to minimize the possibility of ex-ante as well as ex-post opportunism of the agents involved and facilitate control over the rent. Long-term contracts via ACR, with new and reserve energy, are safer but require a secure and stable institutional environment. Long-term contracts via $\mathrm{ACL}$ are less secure but do not depend so much on the Government. Short-term contracts of existing energy via ACR and spot market trading do not protect the specific assets but allow for short-term gains and better use of the installed capacity. Contracts of existing energy via ACR are quite safe, but the spot market transactions present a high risk because of the judicialization issues, which may reduce the percentage of installed capacity used and undermine the profitability of investments. Thus, plural forms of the "between" and "combo" types can be considered as the safest governance structures, minimizing the fragility of each arrangement and the problems of uncertainty due to the institutional environment.

Finally, it is important to point out if these plural forms are stable or if the governance structure of the sector is converging to a dominant institutional arrangement, as estimated by Williamson in TCE theory. In the last years, ACL contracts have increased regularly and reached $48.7 \%$ of the energy marketed in Brazil in 2016, against $46.8 \%$ in 2015 . When considering only the electric energy from biomass (cane, black liquor, firewood, and tree residues), this percentage reached 64\% in 2016 (Associação Brasileira de Comercializadores de Energia, 2017). ACL contracts integrate the need for stability linked to the specificity of the assets, to a weak institutional environment, and problems in the spot market. However, energy companies from sugarcane biomass continue to participate in the ACR auctions and to sell part of their production in the spot market, suggesting the continuation of the plural forms.

This work indicates a good alignment of institutional arrangements with the characteristics of transactions, especially when considering the impact of uncertainty in the adoption of the plural forms. The preference for ACL contracts and numerous short-term transactions indicate a lack of trust in the existing institutions. The solution would be to strengthen the regulatory agencies, with independence from the Government and guarantees for long-term contracts.

Although the research was carried out in the state of Mato Grosso do Sul, most of the companies established in this state have units in other Brazilian states as well, with similar 
policies. The interview conducted with a former director of the São Martinho group allowed to confirm the similarity of the situation in other Brazilian states and also allowed to extend the final considerations to the entire sugarcane sector in Brazil.

The strengthening of the production of energy from sugarcane biomass should become increasingly important in Brazil due to climatic changes, which are expected to alter the water regime in the main hydroelectric power generation regions. As sugarcane mills produce more during the dry season, this sector offers an alternative to the hydroelectric power plants. At the same time, the reduction of sugar consumption in developed countries and the development of electric cars, which should increasingly reduce ethanol consumption, mean that electricity production to become an essential product for this sector.

Funding: This work was supported by the Foundation to Support the Development of Education, Science, and Technology of Mato Grosso do Sul State (FUNDECT).

\section{References}

Agência Nacional de Energia Elétrica - ANEEL (2014). Banco de Informações de geração: matriz de energia elétrica. Brasília: BIG/ANEEL.

Agência Nacional de Energia Elétrica - ANEEL. (2015a). Banco de Informações de geração: matriz de energia elétrica. Brasília: BIG/ANEEL.

Agência Nacional de Energia Elétrica - ANEEL. (2015b). Leilão de energia de reserva - $3^{\circ}$ LER. Minuta do Leilão $n^{\circ}$ 11/2015 - Processo $n^{\circ}$ 48500.006535/2014-93. Brasília: BIG/ANEEL.

Altman, I., \& Johnson, T. (2008). The choice of organizational form as a non-technical barrier to agrobioenergy industry development. Biomass and Bioenergy, 32(1), 28-34.

Araujo, J., Costa, A. M., Correia, T., \& Melo, E. (2008). Energy contracting in Brazil and electricity prices. International Journal of Energy Sector Management, 2(1), 36-51.

Associação Brasileira de Comercializadores de Energia - ABRACEEL. (2017). Energia livre: isso é da sua conta (No. 2). Brasília: ABRACEEL. Recuperado em 15 de julho de 2020, de http://www.abraceel.com.br/userfiles//Versao_Final_Relatorio_Anual_Abraceel_2016.pdf

Associação dos Produtores de Bioenergia de Mato Grosso do Sul - BIOSUL. (2015). Histórico de produção em Mato Grosso do Sul.

Associação dos Produtores de Bioenergia de Mato Grosso do Sul - BIOSUL. (2019). Série histórica: exportação de bioeletricidade. Mato Grosso do Sul.

Bocci, E., Di Carlo, A., \& Marcelo, D. (2009). Power plant perspectives for sugarcane mills. Energy, 34(5), 689-698.

Brasil. (2004a). Decreto n 5.163 de 30 de julho de 2004. Regulamenta a comercialização de energia elétrica, o processo de outorga de concessões e de autorizações de geração de energia elétrica, e dá outras providências. Diário Oficial [da] República Federativa do Brasil, Brasília.

Brasil. (2004b). Lei nº 10.847 de 15 de março de 2004. Autoriza a criação da Empresa de Pesquisa Energética - EPE e dá outras providências. Diário Oficial [da] República Federativa do Brasil, Brasília.

Brasil. (2004c). Lei n 10.848 de 15 de março de 2004. Dispõe sobre a comercialização de energia elétrica. Diário Oficial [da] República Federativa do Brasil, Brasília.

Brasil. (2006). Resolução Conama n³82, de 26 de dezembro de 2006. Estabelece os limites máximos de emissão de poluentes atmosféricos para fontes fixas. Diário Oficial [da] República Federativa do Brasil, Brasília.

Brasil. (2007). Decreto $n^{\circ} 6.048$ de 27 de fevereiro de 2007. Altera os arts. 11, 19, 27, 34 e 36 do Decreto no 5.163, de 30 de julho de 2004, que regulamenta a comercialização de energia Elétrica, o processo de outorga de concessões e de autorizações de geração de energia elétrica. Diário Oficial [da] República Federativa do Brasil, Brasília.

Brasil. (2012). Decreto n 7.805 de 14 de setembro de 2012. Regulamenta a Medida Provisória no 579, de 11 de setembro de 2012, que dispõe sobre as concessões de geração, transmissão e distribuição de energia elétrica, sobre a redução dos encargos setoriais, sobre a modicidade tarifária, e dá outras providências. Diário Oficial [da] República Federativa do Brasil, Brasília.

Brasil. Ministério de Minas e Energia - MME. (2013). Balanço Energético Nacional 2013: Ano base 2012. Rio de Janeiro: Empresa de Pesquisa Energética. Recuperado em 8 de dezembro de 2020, de 
https://www.epe.gov.br/pt/publicacoes-dados-abertos/publicacoes/Balanco-Energetico-Nacional2013

Brasil. Ministério de Minas e Energia - MME. (2016). Resenha energética brasileira. Exercício de 2015. Brasília. Recuperado em 15 de julho de 2020, de http://www.aben.com.br/Arquivos/456/456.pdf

Câmara de Comercialização de Energia Elétrica - CCEE. (2015). Resultado consolidado dos leilões 12/2015. Recuperado em 15 de julho de 2020, de https://www.ccee.org.br/ccee/documentos/CCEE_360479

Câmara de Comercialização de Energia Elétrica - CCEE. (2020a). Comercialização. Recuperado em 15 de julho de 2020, de https://www.ccee.org.br/portal/faces/pages_publico/ondeatuamos/comercializacao?_afrLoop=94584815257737\&_adf.ctrlstate=dulfvjyyu_14\#!\%40\%40\%3F_afrLoop\%3D94584815257737\%26_adf.ctrl-state\%3Ddulfvjyyu_18

Câmara de Comercialização de Energia Elétrica - CCEE. (2020b). Contratos: regras de comercialização. Versão 2020.2. Recuperado em 15 de julho de 2020, de www.ccee.org.br/ccee/documentos/CCEE_644664

Câmara de Comercialização de Energia Elétrica - CCEE. (2020c). Setor elétrico: com quem se relaciona. Recuperado em 15 de julho de 2020, de https://www.ccee.org.br/portal/faces/pages_publico/ondeatuamos/com_quem_se_relaciona?_adf.ctrl-state=jtvdmdluj_184\&_afrLoop=101449679318148\#!

Coase, R. H. (1937). The nature of the firm. Economica. New Series, 4(16), 386-405.

Coutinho, P. C., \& Oliveira, A. R. (2013). Trading forward in the Brazilian electricity market. International Journal of Energy Economics and Policy, 3(3), 272-287.

Dalbem, M. C., Brandão, L. E. T., \& Gomes, L. L. (2014). Can the regulated market help foster a free market for wind energy in Brazil? Energy Policy, 66, 303-311.

Defante, L. R., Vilpoux, O. F., \& Sauer, L. (2018). Evolução da produção de cana-de-açúcar no Estado de Mato Grosso. Informe Gepec, 22(1), 150-169.

Delmas, M., \& Tokat, Y. (2005). Deregulation, governance structures, and efficiency: The U.S. electric utility sector. Strategic Management Journal, 26(5), 441-460.

Deshmukh, R., Jacobson, A., Chamberlin, C., \& Kammen, D. (2013). Thermal gasification or direct combustion: comparison of advanced cogeneration system in sugarcane industry. Biomass and Bioenergy, 5(5), 163-174.

Erdogdu, E. (2013). A cross-country analysis of electricity market reforms : Potential contribution of New Institutional Economics. Energy Economics, 39, 239-251.

Fabrizio, K. R. (2013). The effect of regulatory uncertainty on investment: evidence from renewable energy generation. Journal of Law Economics and Organization, 29(4), 765-798.

Finon, D., \& Perez, Y. (2007). The social efficiency of instruments of promotion of renewable energies : a transaction-cost perspective. Ecological Economics, 62(1), 77-92.

Garcia, M., Vilpoux, O. F., \& Cereda, M. P. (2018). Distributed electricity generation from sugarcane for agricultural irrigation: a case study from the midwest region of Brazil. Utilities Policy, 50, 207-210.

Ghosh, R., \& Kathuria, V. (2015). Gas based power generation in India : lessons from a transaction cost analysis. Energy Strategy Reviews, 8, 1-7.

Gomes, C. F., \& Maia, A. C. C. (2013). Ordenação de alternativas de biomassa utilizando o apoio multicritério à decisão. Produção, 23(3), 488-499.

Henisz, W. J., \& Zelner, B. A. (2001). The institutional environment for telecommunications investment. Journal of Economics \& Management Strategy, 10(1), 123-147.

Higashi, S. Y., Fagundes, M. B. B., Caleman, S. M. Q., Sauer, L., \& Saes, M. S. (2017). Plural forms of governance at central supply markets. Revista de Administração Contemporânea, 21(6), 743-763.

Hofsetz, K., \& Silva, M. A. (2012). Brazilian sugarcane bagasse: energy and non-energy consumption. Biomass and Bioenergy, 46, 564-573.

International Energy Agency - IEA (2013). World Energy Outlook 2013. Paris: IEA. Recuperado em 15 de julho de 2020, de https://www.iea.org/reports/world-energy-outlook-2013

Langniss, O., \& Praetorius, B. (2006). How much market do market-based instruments create? An analysis for the case of "' white "' certificates. Energy Policy, 34(2), 200-211.

Lopes, D., \& Leite, A. (2016). What accounts for plural forms of governance structure in the same industry or firm: the case of the Brazilian Electricity Industry. Brazilian Administration Review, 13(4), 1-18. 
Ménard, C. (2004). The economics of hybrid organizations. Journal of Institutional and Theoretical Economics, 160(3), 345-376.

Ménard, C. (2013). Plural forms of organization: where do we stand? Managerial and Decision Economics, 34(3-5), 124-139.

Ménard, C. (2014). Embedding organizational arrangements : towards a general model. Journal of Institutional Economics, 10(4), 567-589.

Ménard, C., \& Shirley, M. M. (2014). The future of new institutional economics: from early intuitions to a new paradigm? Journal of Institutional Economics, 10(4), 541-565.

Michelazzo, M. B., \& Braunbeck, O. A. (2008). Análise de seis sistemas de recolhimento do palhiço na colheita mecanizada da cana-de-açúcar. Revista Brasileira de Engenharia Agrícola e Ambiental, 12(5), 546-552.

Nepal, R., Menezes, F., \& Jamasb, T. (2014). Network regulation and regulatory institutional reform : Revisiting the case of Australia. Energy Policy, 73, 259-268.

Niesten, E., Jolink, A., Lopes de Sousa Jabbour, A. B., Chappin, M., \& Lozano, R. (2017). The impact of governance and institutions on sustainable performance. Journal of Cleaner Production, 155(2), 1-6.

North, D. (1990). Institutions, institutional change and economic performance. Cambridge University Press.

North, D. (2005). Understanding the process of economic change. Princeton: Princeton University Press.

Praetorius, B., \& Bleyl, J. W. (2006). Improving the institutional structures for disseminating energy efficiency in emerging nations: a case study for energy agencies in South Africa. Energy Policy, 34(13), 1520-1531.

Raynaud, E., Schnaider, P. S. B., \& Saes, M. S. M. (2019). Surveying the economics of plural modes of organization. Journal of Economic Surveys, 33(4), 1151-1172.

Rego, E. E., \& Parente, V. (2013). Brazilian experience in electricity auctions: Comparing outcomes from new and old energy auctions as well as the application of the hybrid Anglo-Dutch design. Energy Policy, 55, 511-520.

Rendeiro, G., Macedo, E. N., Pinheiro, G., \& Pinho, J. (2011). Analysis on the feasibility of biomass power plants adding to the electric power system e Economic, regulatory and market aspects e State of Pará, Brazil. Renewable Energy, 36(6), 1678-1684.

Sander, M. (2016). The rise of governments in global oil governance : Historical dynamics, transaction cost economics, and contemporary implications. Energy Research \& Social Science, 17, 82-93.

Scaramucci, J., Perin, C., Pulino, P., Bordoni, O. F. J. G., da Cunha, M. P., \& Cortez, L. A. B. (2006). Energy from sugarcane bagasse under electricity rationing in Brazil: a computable general equilibrium model. Energy Policy, 34(9), 986-992.

Schnaider, P. S. B., Ménard, C., \& Saes, M. S. M. (2018). Heterogeneity of plural forms: a revised transaction cost approach. Managerial and Decision Economics, 39(6), 652-663. http://dx.doi.org/10.1002/mde.2935

Signorini, G., Ross, R. B., \& Peterson, H. C. (2015a). Historical analysis of institutions and organizations: the case of the Brazilian electricity sector. Journal of Institutional Economics, 11(1), 191-212.

Signorini, G., Ross, R. B., \& Peterson, H. C. (2015b). Governance strategies and transaction costs in a renovated electricity market. Energy Economics, 52, 151-159.

Silva, N. F., Rosa, L. P., Freitas, M. A. V., \& Pereira, M. G. (2013). Wind energy in Brazil : from the power sector's expansion crisis model to the favorable environment. Renewable \& Sustainable Energy Reviews, 22, 686-697.

Souza, F. C., \& Legey, L. F. L. (2010). Dynamics of risk management tools and auctions in the second phase of the Brazilian Electricity Market reform. Energy Policy, 38(4), 1715-1733.

Souza, Z. J. (2017). Prioridade: resolver a judicialização no Mercado de Curto Prazo! União dos Produtores de Bioenergia (UDOP ), Fórum de Articulistas. Recuperado em 16 de julho de 2020, de https://www.udop.com.br/noticia/2017/11/08/prioridade-resolver-a-judicializacao-no-mercado-decurto-prazo.html

Spanjer, A. R. (2009). Regulatory intervention on the dynamic European gas market: neoclassical economics or transaction cost economics? Energy Policy, 37(8), 3250-3258.

União da Industria de Cana de Açúcar - ÚNICA. (2017). Boletim: a bioeletricidade da cana em números: abril de 2017. São Paulo: UNICA. 
União da Industria de Cana de Açúcar - ÚNICA. (2018). UNICADATA: produção. São Paulo: UNICA. Recuperado em 16 de julho de 2020, de http://www.unicadata.com.br/historico-de-areaibge.php?idMn=33\&tipoHistorico=5

Ursaia, G. C., Guerra, J. B. A., Youssef, Y. A., \& Lordemann, J. A. (2013). O quadro político e institucional do setor energético brasileiro (Working Paper, No. 92). Portugal, Leiria: GlobAdvantage of Center of Research in International Business e Strategy.

Vahl, F. P., Rüther, R., \& Casarotto Filho, N. (2013). The influence of distributed generation penetration levels on energy markets. Energy Policy, 62, 226-235.

Williamson, O. E. (1985). The economic institutions of capitalism. New York: The Free Press.

Williamson, O. E. (1996). The mechanisms of governance. New York: Oxford University.

Williamson, O. E. (1999). Public and private bureaucracies: a transaction cost economics perspective. Journal of Law Economics and Organization, 15(1), 306-342.

Submetido: 23/apr/2019

Aceito: $15 /$ oct $/ 2020$

JEL: D23 K32 L14 L22 L51 